was commenced owing to the fact that wire nails had become very difficult to obtain in India, while the demand for packing cases, not least for army requirements, had increased enormously. Experiments were carried out to see how bamboo nails compared in holding power and other qualities with wire nails. The results of the tests are given; and sketches of largescale production of bamboo nails are included and the process of manufacture described.

Truly India is a fortunate country when her carefully supervised forest wealth enables her to confront one difficulty after another in times of dire stress through the work of her research officers. "It has been found", says the author, "that glued bamboo nails have a greater holding power than plain iron nails under a steady pull. But when shocks and transportation hazards are met with, their holding power diminishes". A small percentage of iron nails in a packing case is, therefore, necessary, especially for fixing the battens by clinching. It was found by actual tests that if 25 per cent iron nails and 75 per cent bamboo nails are used, a strong and serviceable box results, with a very considerable saving in costs of manufacture.

Another use of the bamboo has been found in the manufacture of pill or ointment boxes. Due to a shortage of metal, various substitutes have had to be used in the construction of containers; thus plywood containers have already been mentioned in NATURE (Ind.For. Leaf. 24 and 26). In Leaflet 39 (1943) Sultan Mohammed discusses the method of making from bamboo small pill and ointment boxes. Details of manufacture are given including some information on suitable coatings and linings. It is said that a fairly competent turner will find no difficulty in making these boxes with the aid of a lathe and ordinary tools. The description is of interest: "A bamboo container consists of a short length of bamboo (according to size of container required) which forms the walls of the body and lid of the container. The top and the bottom are made of thin three plywood and are provided with a locking device so that, if the top becomes loose due to climatic changes, the lid will still be held tight. The container is usually coated or painted, both inside and outside, with the object of retarding the absorption of moisture by sealing the pores of the bamboo, and to give a smooth clean finish."

\section{THE SCIENCE OF TOMATO GROWING}

$\mathrm{T}$

HE Cheshunt Experimental and Research Station has devoted its energies during war-time wholly to the elucidation of problems connected with food crops. Reports of investigations on the tomato occupy most of the twenty-eighth annual report, for 1942, of the Station (from the director, Dr. W. F. Bewley, The Nursery and Market Garden Industries' Development Society, Ltd., Turner's Hill, Cheshunt, Herts, 1943). Trials of the value of muriate of potash as against sulphate of potash resulted in a small, though scarcely significant, increase of crop in favour of the sulphate. No harmful foliage effects were observed when muriate was added, and it would seem that widespread doubts about the suitability of muriate of potash for the indoor tomato crop are now dispelled.

Much research has been devoted to diseases and pests of the tomato. Two varieties, Manx Marvel and Riverside, showed significant resistance to the wilt fungus Verticillium albo-atrum. Tomato stemrot caused by the fungus Didymella lycopersici caused widespread damage in 1942 to plants growing in the greenhouse and in the open. The disease appears to be carried from crop to crop on wire supports and strings, and may be controlled by suitable methods of hygiene. Experiments have also been made with fungicides as soil treatment, or applied as sprays and dusts to the plant, or as a protection of the 'collar', where infection normally occurs in greenhouse tomatoes.

Control of the wireworm pest by trapping with carrot bait gave rather disappointing results, and the elimination of these larvæ still remains one of the outstanding problems of pest control. Other negative results were obtained with sprays containing tartar-emetic and glycerine, advocated in the United States against the red-spider mite, and with potassium iodide solution for the prevention of damage by the root-knot eelworm.

Tomatoes in sand culture exhibited clear-cut symptoms when deprived of boron, manganese and magnesium. Omission of boron and magnesium from the culture solution produced marked stunting, and boron deficiency caused a leaf scorch similar to that sometimes associated with acute potassium starva. tion. Lack of magnesium induced a withering of the tips of leaflets, whereas the absence of manganese brought about a mottling of the leaf with uniform yellow specks. The report contains details of these and other investigations in the form of short papers by the authors of each subject for research.

\section{HYDROGEN EXCHANGE REACTIONS}

TN two papers (J. Chem. Soc., 361, 367; J943) H. V. A. Briscoe and co-workers describe the results of experiments on the interchange of hydrogen isotopes with complex salts, ammines of cobalt, and platinum and palladium being studied. The hydrogen of $\left[\mathrm{Co}\left(\mathrm{NH}_{3}\right)_{6}\right] \mathrm{Cl}_{3}$ and [Co $\left.\mathrm{en}_{3}\right] \mathrm{Cl}_{3}$ (en = ethylenediamine) undergoes isotope exchange with heavy water $\left(D_{2} O\right)$ in solutions, the interchange following a unimolecular law with a rate inversely proportional to the hydrogen ion concentration but practically independent of the ammine concentration or its deuterium content. The exchange mechanism is explained by assuming that the metal ammine group $M-\mathrm{NH}_{3}$ can ionize as an acid : $M-\mathrm{NH}_{3}=$ $M-\mathrm{NH}_{2}^{\prime}+\mathrm{H} \cdot$, this being parallel to the ionization of aquo-ammines, which form hydroxo-ammines. There is some evidence that the case of acid dissociation runs parallel with the stability of the ammines. The reaction mechanism is very fully discussed in the papers on the basis of the kinetics.

The rate of interchange of hydrogen isotopes with ammines of different metals decreases in the order $\mathrm{Co}>\mathrm{Pt}>\mathrm{Pd}$ and runs parallel to the complex ions. In the case of $\left[\mathrm{Pd}\left(\mathrm{NH}_{3}\right)_{4}\right] \mathrm{Cl}_{2}$ the interchange mechanism is complex; in addition to the acid dissociation mechanism, it reacts in acid solution by reversible dissociation of ammonia from the complex. This points to a continuous gradation between the two extreme types of ammonia complexes represented by the stable metal ammines of the $\left[\mathrm{Co}\left(\mathrm{NH}_{3}\right)_{6}\right] \mathrm{Cl}_{3}$ 
type and the unstable ammoniates of bivalent cobalt, nickel, copper, etc. The function of the nitrogen atom of the ammonia molecules as a centre of coordination has perhaps not been sufficiently emphasized in the past, and its tendency to assume a configuration similar to that of the ammonium ion in the stable compounds, which then dissociate as substituted ammonium salts, should apparently also be taken into account.

\section{FORTHCOMING EVENTS}

\section{(Meetings marked with an asterisk * are open to the public)}

Tuesday, December 28

ROYaL INSTITUTION (at 21 Albemarle Street, London, W.1), at 2.30 p.m.-Prof. W. N. da C. Andrade, F.R.S.: "Vibrations and

Thursday, December 30

RoYar Institution (at 21 Albemarle Street, London, W.1), at 2.30 p.m.-Prof. E. N. da C. Andrade, F.R.S.: "Vibrations and Waves", 2: "Wave Properties in General"."

Friday, December 31

Institution of MECHanical ENGINenRs (at Storey's Gate, St. James's Park, London, S.W.1), at 5.30 p.m.-Mr. A. J. Philpot: "Paints and Protective Finishes for Metals".

\section{Saturday, January I}

ROYAL INSTITUTION (at 21 Albemarle Street, London, W.1), at 2.30 p.m.- Prof. E. N. da C. Andrade, F.R.S.: "Vibrations and

\section{APPOINTMENTS VACANT}

AppuIcations are invited for the following appointments on or before the dates mentioned :

TECHNICIAN FOR THE VHTERINARY LABORATORY-The Secretary, West of Scotland Agricultural College, 6 Blythswood Square, Glasgow (December 28).

Master to be responsible for the teaching of Mathematics at the Bristol Junior Technical School-The Chief Education Officer, 2 Cecil Road, Clifton, Bristol 8 (December 29).

Assistant LeCTURER in the Mining Department-The Principal, County Mining and Technical School, Nuneaton, Warwickshire (December 31).

PRINCIPA (temporary) of the Bridgend Mining and Technical Institute and Junior Technical Schools-The Director of Education, County Hall, Cardiff (January 3 ).

ASSISTANT MASTER to teach MATHEMaTICs in the Day School-The Clerk to the Governors, South-East Essex Technical College and School of Art, Longbridge Road, Dagenham, Essex (January 3).

Mu $\triangle R Y$ BIOLOF-The Clerk to the Governors, South-West Bssex Tech. nical College and School of Art, Forest Road, Walthamstow, London, E.17 (January 3)

Assistant (part-time) IN SPEEch Training in the Department of Education-The Registrar, The University, Manchester 13 (January 10).

SCreNCE Master, mainly for CHeMISTRX, up to University Scholarship standard, at the City of London School-The Town Clerk, 55-61 Moorgate, London, E.C.2 (January 12).

CHAIR OF CHEMISTRY - The Principal, University College of Wales, Aberystwyth (January 15)

REgIUS PROFESSOR OF ZOOIOGY at Glasgow University-The Private Secretary, Scottish Office, Fielden House, 10 Great College Street, London, S.W.1 (January 17).

DEMONSTRATOR IN ANATOMY (male)-The Secretary, Guy's Hospital Medical School, London Bridge, London, S.E.1.

LABORATORY STEWARD for the Chemistry Department-The Principal, Coventry Technical College, Coventry.

ASSISTANT INSPECTORS I and II (covering Groups A and B) for posts (London and Provinces) in a Government Department. For Group A posts sound technical and practical training in Mechanical Engineering is required, preferably in Heavy or Marine Engineering or in Modern Engineering Production Methods ; for Group B posts sound technical and practical training and experience in Mechanical Engineering is required, with special knowledge of Foundry Practice, the Nut and Bolt Industry, the Metallurgy of Ferrous and NonFerrous Metals, or the Armour Plate Industry-The Ministry of Labour and National Service, Central (Technical and Scientiflc) Register, Advertising Section, Alexandra House, Kingsway, London, which application is being made).

WORKS ENGINERR (Order No. 275) with good experience in Plant Maintenance (including Electrical) and Lay-outs of New Projects required; a METAL SHops SUPERINTENDENT (Order No. 262), with Machine shop experience essential and Coppersmith experience desirable; an Assistant CHIEF of PRODUCTION CoNTrol (Order No. 274), must be thoroughly conversant with Engineering Procedure and Operation of Works Documents, with good administrative ability and experience in dealing with large staff-The Ministry of
Labour and National Service, A.O., 16 Westwood Road, Southampton (quoting appropriate Order No.)

Plantation Assistants in the Cameroons under the Custodian of Enemy Property, Nigeria-The Ministry of Labour and National ervice, Central (Technical and Scientiflc) Register, Advertising Seeion, Alexandra House, Kingsway, London, W.C.2 (quoting Reference No. F.1888)

CECTURER (temporary) in the DEPARTMENT of BUILDING and STructurat EngINegrivg-The Principal, Central Technical College, Suffolk Street, Birmingham 1 .

Chinf Planning Enginker at a well-known Airframe Manufactur ing Concern in the London area-The Ministry of Labour and National Service, Central (Technical and Scientiffe) Register, Advertising Section, Alexandra House, Kingsway, London, W.C.2 (quoting Reference No. C.1951XA)

Gradiate Assistant Master to teach General SoIence with Mathamatics in Day Technical School and Evening Institute--The Principal, Technical Institute, 28 Beckenham Road, Beckenham Kent.

ASsistant Lecturen to teach ENGINEering SUbJECTs, including ScIENCE, Mathematics and DRAwING to day and evening studentsThe Principal, Forest of Dean Mining and Technical School, Cinderford, Gloucestershire.

ASSISTANT MASTER or Mistress to teach Geography, and an Assistant MASTER FOR ENGINEERING SUBJECTs, at the Burton-uponTrent Technical Institute and Junior Technical School-The Secretary and Director of Education, Education Offices, Guild Street, Burtonupon-Trent.

\section{REPORTS and other PUBLICATIONS}

(not included in the monthly Books Supplement)

\section{Great Britain and Ireland}

Geological Survey of Great Britain. Wartime Pamphlet No. 13: Limestones of Scotland, Area 8 : Orkney and Shetland. By D. Haldane: with Analyses by H. G. M. Hardie. Pp. 13. (London. Ge0. logical Survey and Museum.) 9d. [1111 Imperial bureau of Animal Breeding and Genetics. Gestation Periods: a Table and Bibliography, Compiled by J. H. Kenneth. Pp. 23. (Edinburgh and London: Oliver and Boyd, Ltd.) 28. Iron and Steel Institute. Special Report No 29: Review of the Work of the Joint Research Committees 1924-1943 of the Iron and Steel Institute and the British Iron and Steel Federation. Pp. yili 176. (London: Iron and Steel Institute.) Transactions of the Royal Society of Edinburgh. Vol. 61, Part 1, Native Cultivated "Diploid" Potatoes. By Dr. H. C. Choudhuri. Pp. 113-136. 38. Vol. 61, Part 1, No. 4: Inheritance of Resistance to Two Strains of Blight (Phytophthora infestans de Bary) in Potatoes. By Dr. William Black. Pp. 137-148. 1s. 6d. (Edinburgh and London :

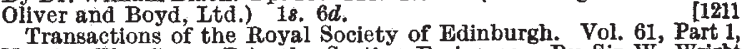
No. 1 : The Genus Primula, Section Farinosae. By Sir W. Wright Smith and Dr. H. R. Fletcher. Pp. 69. (Edinburgh and London: Oliver and Boyd, Ltd.) $88.6 d$.

[1911

\section{Other Countries}

Indian Forest Bulletin. Utilisation (New Series), No, 120: Studies in Permeability. Part 1: A Preliminary Note on the Permeability of Wood and other Materials to Air. By D. Narayanamurti and A. Purushotham. Pp. $16+3$ plates. 6 annas; $7 \dot{d}$. Indian Forest Leaflet. Purushotham. Pp. $16+3$ plates. 6 annas; $7 d$. Indian Forest Leaflet. Utilisation, No. 40: Studies on Adhesives, Part $4:$ Further Note on Prolamin Adhesives. By D. Narayanamurti and V. Ranganathan. suitable for the Seasoning of Cooperage Woods and Packing Case Timbers. By M. A. Rehman. Pp. ii $+6+1$ plate. 6 annas; 9d. Utilisation, No. 45: Preliminary Studies on Improved Wood, Part 2: Lam inated Wood. By D. Narayanamurti and Kartar Singh. Pp. 8+ plates. 6 annas ; 9d. (Dehra Dun: Forest Research Institute.) [1410 Smithsonian Institution. War Background Studies, No. 13: Alaskr, America's Continental Frontier Outpost. By Ernest P. Walker.
(Publication 3733.) Pp. iv $+57+21$ plates. (Washington, D.C. (Publication 3733.) Pp. iv $+57+21$ plates. (Washington, Digio Smithsonian Institution.) Art. 4: Fossil Lizards of Mongolia. By Charles W. Gilmore. Pp 361-384 +plate 52. (New York: American Museum of Natural

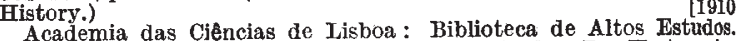
Academia das Ciências de Lisboa: Biblioteca de Altos Estudos. Relaçõès científicas entre Portugal e a Grä-Bretanha. Por H. Amorim Ferreira. Pp. viii + 76. (Lisboa : Academia das Cisncias.) Carnegie Institution of Washington: Department of Terrestria
Tagnetism. Scientific Results of Cruise VII of the Carnegie during 1928-1929 under command of Captain J. P. Ault. Biology, 3 : Studie in the Morphology, Taxonomy and Fcology of the Peridiniales. By Herbert W. Graham. (Publication 542.) Pp. vii +129. 1.50 dollars. Meteorology, 1: Meteorological Results of Cruise VII of the Carmegie, 1928-1929. By Woodrow C. Jacobs and Katherine B. Clarke. (Pub lication 544.) Pp. v+168. 1.50 dollars. Meteorology, 2: UpperWind Observations and Results obtained on Cruise VII of the Carnegie. By Andrew Thomson. (Publication 547.) Pp. vii +93. 75 cents. (Washington, D.C.: Smithsonian Institution.) Proceedings of the American Philosophical Society. Vol, 87, No. (July 14, 1943): The Early History of Science and Learning in America, Papers read before the American Philosophical Society, Midwinter and Autumn Meetings,

Brocklyn Botanic Garden Record. Vol. 32, No. 3 : The Medicinal Plant Garden of the Brooklyn Botanic Garden. (Guide No. 16.) Pp 165-210. (Brooklyn, N.Y.: Brooklyn Institute of Arts and Sciences.) 25 cents. 